\title{
1. What I have learned about teaching entrepreneurship: perspectives of five master educators
}

\author{
Jerome S. Engel, Minet Schindehutte, Heidi M. \\ Neck, Ray Smilor and Bill Rossi
}

\section{INTRODUCTION}

The editors of this volume asked five leading educators what they have learned about teaching entrepreneurship. We reached out to faculty members acknowledged by their peers, leading academic organizations, their institutions and their students to be among the very best in entrepreneurship education. Each of these individuals has over a decade of experience in the entrepreneurship classroom, and has witnessed the rapid evolution of a very dynamic discipline. In the pages that follow, they provide unique perspectives on what is taught and how it is taught. The opening piece captures a bit of the trajectory of entrepreneurship education and the contemporary challenge, while the four that follow provide personal insights on teaching entrepreneurship in ways that meet that challenge.

\section{Jerome S. Engel}

We have made great progress in entrepreneurship education. When I first came to Berkeley in 1991 after a successful career in industry, fundamental challenges to the role of entrepreneurship in education were open and raw. One would frequently be asked:

- Can entrepreneurship be taught?

- Does entrepreneurship belong in the university?

Thanks to educators like the contributors to this volume and their predecessors, these basic challenges have been laid to rest. It is understood that entrepreneurship is a life skill with broad applicability. It is important and helpful to many beyond those who choose to pursue entrepreneurship 
as a career. Like mathematics, it is broadly relevant and not limited just to those who choose to become mathematicians.

It is now our turn to ask:

- What are entrepreneurship education's best practices?

- How can we best utilize entrepreneurship education to mobilize the resources and talents to create value for our students and their stakeholders, for our communities and for society as a whole?

Reflecting on my experience as an entrepreneurship educator over the last 25 years, I believe that we clearly have made great progress in developing the educational curriculum and experiential methods to help our students build successful entrepreneurial ventures and careers. I will focus here on three big challenges that we now face as we broaden our influence and impact:

1. the importance of entrepreneurship education to corporate innovation strategy broadly;

2. the importance of entrepreneurship education to university education writ large;

3. the importance of entrepreneurship education to the creation of healthy innovation communities and economies, for example clusters of innovation.

\section{LET ME SHARE A HISTORICAL PERSPECTIVE}

In the beginning, entrepreneurship education was the domain of the business school.

\section{In the $1980 \mathrm{~s} \ldots$}

When we thought of entrepreneurship education, if we thought of it at all, we thought of "Small Business" - SMEs. Entrepreneurship was often a stand-alone cross-disciplinary capstone course where students built business plans and integrated the skills they had learned in their marketing, finance and management courses. Case studies were the new pedagogical innovation, and experiential learning was limited to internships or student projects for smaller firms. 
In the $1990 \mathrm{~s} \ldots$

We discovered the startup. Especially with the arrival of the internet, the opportunity for any student to start his or her own business became evident. Business plan competitions grew like mushrooms. When we founded our competition at Berkeley in the mid 1990s it was still considered an innovation, though we were following in the well-worn path of Moot Corp (University of Texas at Austin) and others. We still taught entrepreneurship with case studies and business plans. In fact, the common philosophy was that technology startups were just smaller versions of big businesses. With their potential for explosive growth they were exciting opportunities - and we focused on teaching the articulation of the business plan for the management of rapid growth. We had not yet recognized and isolated for analysis and teaching the very special attribute of a startup, that it was a temporary state meant for experimentation to discover and validate a business model, which could then be executed with greater certainty and justifiably greater capital. This insight would have to await the next major disruption looming on the horizon.

\section{The Turn of the Century Brought a New Reality ...}

On March 10, 2000 the NASDAQ index reached a peak of \$5048. By October 9, 2002 it had collapsed to $\$ 1114$, and it would not start a sustained recovery until November 2008, a full nine years after the bust. With the bursting of the internet bubble, some questioned the value and durability of the entrepreneurial revolution. A leading Silicon Valley venture capital firm published a briefing on internet enterprises for its limited partners headlined with a tombstone engraved R.I.P. - Rest in Peace!

The hiatus of the excesses of the bubble, and the subsequent rebirth of the technology startup opportunity, not only yielded Google and many other global success stories, but also supplied new approaches to discovering opportunity by using less capital and more experimentation. Out of the necessity of the capital crunch of the post-bubble period came the first instances of the entrepreneurial management practices we now know as "Lean" - the Lean Startup or the Lean LaunchPad.

\section{Onward ...}

In the last decade we have seen these methods become well understood and broadly promulgated. We have built new tools. The triad of the business model canvas, customer discovery and the minimum viable product has become ubiquitous. We have developed a new pedagogy. We no longer 
teach that a startup is a smaller version of a big business; rather we now teach that a startup is a temporary organization whose purpose is to discover a viable and scalable business model. We teach evidence-based entrepreneurship. The business plan - while still a valuable management tool - is understood as an execution tool, a tool to be used once the startup is ready to scale. The capstone case study is no longer about someone else's business, but the student's own venture. The professor is no longer the source of all wisdom, but rather a guide who provides an enriched environment for the student's own research and experimentation.

\section{WHAT ARE THE CHALLENGES OF THE NEXT DECADE?}

Three challenges loom.

The first challenge is increasing the impact of what we have learned by accelerating corporate innovation, taking what we have learned about accelerating innovation using the entrepreneurial startup model to the larger stage. Again history is our guide. The modern corporation was the innovation engine of the mid-twentieth century. With massive corporate $\mathrm{R} \& \mathrm{D}$ labs doing some of the best basic research, the modern twentieth-century corporation was a vertically integrated technology commercialization machine. But that model is long gone. With the focus on execution forced on top management by the public financial markets, research departments have been spun off or devolved to product development. True research has been relegated to the university, and innovative new market creation and disruptive innovation outsourced to the startup.

For some, open innovation has simply meant scouting for and acquiring promising startups. The challenge of the next decade for the leaders of entrepreneurship education will be to help the more progressive major corporations go beyond such "open innovation" to become true ambidextrous organizations: organizations that simultaneously execute and experiment. This evolution has already started. Many major corporations are trying in different ways to adopt entrepreneurial business model experimentation. It will be our job to aid them, study the results and synthesize the best practices so we can bring them back to the classroom. That classroom may not initially be the traditional college venue - at first it may well be more suitable for executive education. But those are the experiments that are in our future.

Our second challenge involves entrepreneurship education's role in the entire university. Entrepreneurship education has long left the exclusive purview of the business school. Its relevance to engineering and 
the sciences has never been clearer. Many engineering programs have embraced entrepreneurship, establishing their own faculties and curriculum. Further, the U.S. federal government is embarked on an ambitious program, the National Science Foundation's Innovation Corps (I-Corps), of which I have the privilege to be the National Faculty Director. It is embedding the Lean LaunchPad, an intense 10-week entrepreneurship experiential immersion, into the very core of technology commercialization funding. In just four years since its inception, this program has already trained over $1500 \mathrm{NSF}-$ funded scientists and is now expanding across the technology commercialization efforts of the National Institutes of Health, the Department of Energy and other federal agencies. Beyond these direct efforts, it is having a fundamental ripple effect, impacting entrepreneurship education at universities across the country.

Going beyond its bedrock constituents in business, engineering and the sciences, entrepreneurship education is penetrating and adding value to the pursuit of the arts and the professions, such as journalism, medicine and law. Over 10 years ago when Wake Forrest, a top quality liberal arts college in North Carolina, established the first entrepreneurship curriculum focused on the arts, it was considered extraordinary. Now not only has entrepreneurship education spread into new fields, but the corollary is also true - more and more diverse fields are influencing the advancement of entrepreneurial studies. I need only cite the impact of "design thinking" to make my case.

Now let's turn to our third, and perhaps most impactful, challenge: the role of the university in creating clusters of innovation. Just as entrepreneurship has established itself on campus, the critical contribution of the university in fostering healthy innovation communities has received broader recognition. The university has long been recognized as a provider of the seed corn of knowledge and technology. What is new is the awakening of new pathways for social contribution, through commercialization driven by entrepreneurial ventures. As this effect has become more profound in scale and scope, so the role of the university in fostering and enabling this process has deepened. The university's contribution is important not just for academic relevancy, but for effective public policy as well.

Five years ago, a dozen scholars gathered to raise the question: "What is the role of the university in the creation of an innovation society?" I was gratified that the group chose to anchor their analysis on a framework I had created that extended the work of Michael Porter of Harvard, Henry Etzkowitz of Stanford and other great contributors before them. That framework, which the group came to call the Cluster of Innovation Framework, went beyond its predecessors' focus on the components of a cluster - namely industry concentration, venture capital and such - and 
placed equal or even greater focus on the soft factors of behaviors, such as the mobility of people, money and technology, the propensity for risk taking, acceptance of failure as a learning process, and structures that create alignment of interests, engender teamwork and foster win-win scenarios, such as broad-based equity compensation. Elaborating the Cluster of Innovation Framework led to an important insight - that clusters of innovation did not have to be restricted by physical boundaries. Communities that shared these propensities, these behaviors and these structures could extend beyond physical borders and align with other like communities around the world, forming a new "silk road," a global network of clusters of innovation.

What is the relevance of global clusters of innovation to entrepreneurship education? The active protagonists in these communities are our students! Properly educated, they are better prepared to succeed in today's innovation economy - an economy that is characterized by the rapid emergence, dominance and sunset of technologies, business models, and the businesses that give them life.

The role of the university is central in this new world, and it is undergoing a major make-over, reaching beyond the technical contribution of modern science and engineering and the training of a qualified workforce. The modern university contributes a new resource - the entrepreneurial team - which is at the center of the innovation process.

Entrepreneurship educators stand on the cusp of a new day and new challenges:

- taking what we have learned about innovation from the entrepreneurial model into the broader corporate enterprise, enabling the creation of new management practices that support the ambidextrous organization, one that can both execute and innovate;

- embracing the entire university in entrepreneurship and innovation education, informing and being informed by the contributions of others;

- undertaking our mission as cornerstones in the creation of clusters of innovation in our communities, and as academics using our special access to foster collaboration with other partners around the world so our communities can benefit from the synergies of the global network of clusters of innovation.

These goals may seem audacious - too grand and ambitious - but, if I may borrow liberally from a biblical scholar, if not us, then who? Who else is better situated, or better prepared? These opportunities are at our doorstep. 


\section{Minet Schindehutte}

Five discoveries have shaped my professional life as an entrepreneurship educator. These five lessons came from many encounters on my journey from students in the United States, South Africa and India, from entrepreneurs across the world, and from other teachers who are passionate about entrepreneurship. I share these insights with the hope that one (or more) of them will resonate with others engaged in the lives of students in an entrepreneurship classroom.

\section{BE INSPIRED}

Entrepreneurship is in everything we do, but it is also in between those things. It is a mashup of the three main modes of thinking: philosophy (as the creation of new concepts), art (as the creation of new experiences) and science (as the creation of new functions). Entrepreneurship as art, as science and as philosophy - or rather where the boundaries between art, science and philosophy are transgressed - requires that we recognize its power to transform, that is, to create difference and divergence, rather than to encourage imitation and conformity. Thus, we should not view entrepreneurship as a discipline - something that we can define and know. Rather, we should view entrepreneurship in terms of what it might be able to do: in terms of its potentiality, a becoming for the sake of change itself. Teaching entrepreneurship as a philosophy for life - not an occupation goes beyond facts, and involves a principles-based approach. This set of principles is distilled from experiences that provide guidance on how to live an entrepreneurial life.

Gilles Deleuze, a French philosopher, is my muse. For Deleuze (1990), life is difference, the power to think differently, to become different and to create differences. I did not fully understand what "difference" meant until I encountered Deleuze's philosophy of becoming. Reading Deleuze enriched my life with radically new perspectives on everything. For the first time, I saw potential everywhere. Whereas educators think about the start and end of the course (as learning outcomes), students are always in the middle: on their way to becoming-other - full of infinite potential. I encourage students to write a manifesto for how to lead an entrepreneurial life. Rather than provide them with training materials for an occupation, these personalized principles can guide their everyday choices: an operating system working in the background, reminding them to be inspired and to inspire others. 


\section{BE RELEVANT}

Most of the students in my classroom have no intention of starting a business after graduation (or perhaps ever). They are would-be accountants, marketers, entrepreneurs, scientists, industrial designers and engineers - but they are also authors, musicians, photographers, painters, poets, hobbyists, foodies and sports fans. The one thing they all share is a deep uncertainty about who they are and what they want to do. The lesson I have learned from my students is that most of them are looking for "something" something that is impossible to articulate, yet something (often particular to the individual) that they know they have not yet discovered, and something they will need in whatever they choose to do next. Being a student in the age of uncertainty means learning for entrepreneurship - not about entrepreneurship. In short, "the student's being in the world is more important for her learning than her interests in developing knowledge and understanding in a particular field" (Barnett, 2007, p. 6).

Consequently, I encourage students to approach entrepreneurship (and life!) as an act of creation. Regardless of a chosen professional career, students are creators of their lives - connecting to their true potential is a birthright. Unfortunately, information about how to create the future cannot be found in a textbook. Staying abreast of all new developments, technological advances and entrepreneurs' endeavors is an immensely time-consuming process, but it is a necessary process if one believes that learning is for life, and that teaching entrepreneurship should provide opportunities for students to experience the joy of creating, to flex their "entrepreneurial muscle" and to exceed their own expectations (not strive to meet mine or those of their parents). This belief translates into crafting assessment tools that involve invention - creating something new - rather than regurgitation. It can take the shape of a DIY exam or something more experiential, but in all instances students are challenged to rethink the information they considered as "fact," and to glimpse reality with their imaginations and even their hopes. To a certain extent then, I am a (life) coach rather than a teacher. My role is to create the conditions for behavior change, that is, self-directed learning through self-discovery, selfacceptance and self-expression in which learning is a search for (lifelong) meaning, and learning entrepreneurship is part of a student's way-finding.

\section{BE ADVENTUROUS}

Students do not become more entrepreneurial by reading about entrepreneurship; they have to live it - not one day in the future, but now, and every day. 
I believe the role of the entrepreneurship educator is to challenge, provoke, disrupt, reinvent and be out in front. It requires a willingness to experiment and try new things, to model the innovative behavior required of students. This means setting the entrepreneurship classroom apart from others, making it clear that this is where entrepreneurship happens. Students learn how to think and act entrepreneurially, not what to learn about entrepreneurship. They do not have to start businesses or do internships in high growth businesses to experience entrepreneurship. It can be simulated through transformational experiences - both inside and outside the classroom - with the potential to make a real difference in students' lives, often in unpredictable ways. In the words of Shoshana Felman, "if teaching does not hit upon some sort of crisis, if it does not encounter either the vulnerability or the explosiveness of a (explicit or implicit) critical and unpredictable dimension, it has perhaps not truly taught" (1992, p. 53, italics in original).

In an experience-first approach to teaching entrepreneurship, the "test" precedes the "lesson." I simply create a platform for students - a set of facilitative conditions, rather than constraining rules - and then set them free. Students are invited to participate (with others) in a variety of unconventional activities, from exploratory to symbolic, learning collaboratively and supporting each other, rather than competing for grades. This alternative to one-size-fits-all pedagogies challenges, and indeed resists, education-as-usual and all its associated assumptions, assessments and procedures.

\section{BE INQUISITIVE}

Entrepreneurship is often taught in a problem-solution approach - the predefined problem is associated with an opportunity that is transformed into a venture (the "right answer" to the problem). Unfortunately, the ability to problematize, to linger in that dynamic, generative space in between problems and solutions that remains unresolved, is sometimes neglected. Becoming proficient at intellectual exploration through inquiry - reflexively and relationally, following unexpected detours rather than looking for specific answers - is an important transferable skill, especially when students experience first-hand how moments of insight pierce through the veil of uncertainty.

The message to my students, in the words of the German poet Rainer Maria Rilke, is as follows:

Be patient toward all that is unsolved in your heart and try to love the questions themselves, like locked rooms and like books that are now written in a very 
foreign tongue. Do not now seek the answers, which cannot be given you because you would not be able to live them. And the point is, to live everything. Live the questions now. Perhaps you will then gradually, without noticing it, live along some distant day into the answer. (1993, p. 35)

An inquiry-based approach in which students are encouraged to love the questions themselves - not the-end-of-textbook-chapter questions, but questions that are intrinsically motivated by a wondering-about, questions students ask at a perspective-changing level - can be one of the most valuable tools for entrepreneurship education.

Concomitantly, students are encouraged to become more introspective and contemplative by journaling about their learning experiences (becoming their own sounding board) and to derive relevant principles from the "so what" questions. Apart from taking pride in what they have created, students develop a more personal relationship with course content making connections between self, entrepreneurship and world. I use student e-portfolios to support critical reflection, as well as for assessing experiential competencies. This shifts the purpose of the e-portfolio from an employer focus (portfolio as a hiring or career tool) to a student focus (portfolio as a platform for learning).

\section{BE AUTHENTIC}

This is the final (and most important) lesson. As a beginner entrepreneurship educator, I often wished that I could teach like one of the "masters." It wasn't until I developed my own teaching style - one that was distinctly different from that of my colleagues - that I realized the importance of being true to oneself. It seems so obvious after the fact, but it was not apparent during the early days, especially given the importance attached to student evaluations. The classroom as a space for exploration, questioning and meaning-making is not without challenges. For the teacher it means taking risks, being comfortable with unpredictable outcomes, and letting the reins go in order to find the sweet spot between chaos and order. For the student, it is fraught with ambiguity. Not every student enjoys the "messiness" of an experimental, improvisational classroom in which unexpected possibilities exist. Some students prefer (or rather demand) the familiarity and efficiency of a lecture-based or case-based pedagogy - either because they are uncomfortable with ambiguity and uncertainty, or because they simply resist change. Students' differing responses to how I teach entrepreneurship in an inverted classroom increase the complexity of managing class sessions, especially when class sizes exceed 40 students (which is typical). 


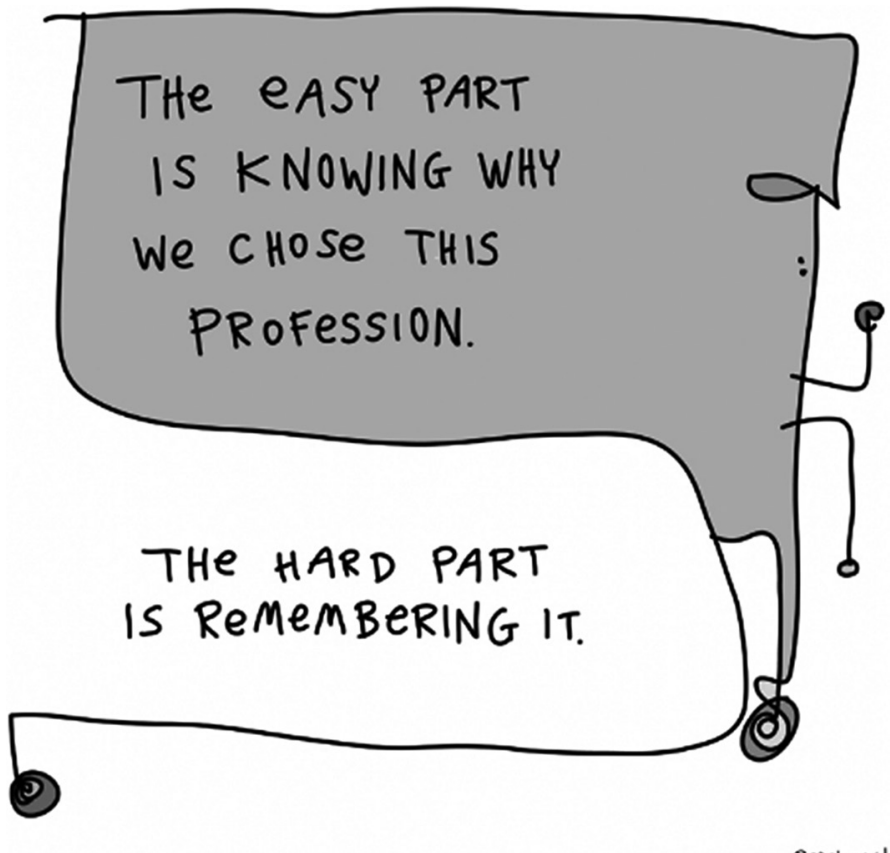

Qgapingvioid

Source: https://www.facebook.com/gapingvoidgallery/posts/1010285655697107.

Unanticipated events invariably unsettle even my most painstakingly planned and well-intended efforts.

Unlike some educators, I find that I am still becoming-teacher - learning with, and from, my students. As in the case of becoming an entrepreneur, these lessons cannot be learned in a book or in a classroom. They are derived from teaching experiences, and after making innumerable mistakes. However, an intense period of failure is often the source of critical insight. Moreover, it almost always prompts re-evaluation of my own, as well as contemporary, pedagogical options. And, although I often cringe in retrospect, I sincerely believe you have to do something that scares you: to feel the fear and do it anyway. Why not? Isn't that what we expect of our entrepreneurship students?

\section{Heidi M. Neck}

When asked to contribute to this chapter of the Annals I was thrilled to be in the company of so many educators that I admire. The challenge to reflect on what I've learned about teaching entrepreneurship was both exciting and terrifying. I was excited to have an excuse to intentionally and 
purposefully reflect on my teaching over the past 15 years yet terrified that I would not have anything of impact to say to those reading this volume presumably other entrepreneurship educators. There were many days where I said to myself, "I will get this short section done today!" On those same days I sat looking at a blank screen experiencing a sort of writer's block regarding the one thing I love most - teaching entrepreneurship. Frustration set in, which only exacerbated my writer's block!

I decided to seek out inspiration. I keep many "teaching files" on my computer and even in hard-copy form in my office. I have files for my student opinion surveys (Babson's version of student ratings of professors), files for new course ideas, files for new exercises to try, files with video links, files with inspirational quotes, files with all types of articles on teaching, and even emails and other correspondence from current and past students. In this latter file I found an article that I had saved from the Babson Magazine (2013). In the Spring issue a few graduates were asked to recall professors or classes that made an impact. To my surprise and delight I was mentioned by a former MBA student, Chet:

Professor Heidi Neck's introductory entrepreneurship course always reminded me of the Elvis lyric, "A little less conversation, a little more action please." She pushed us to stop theorizing and just experiment. She preached about the importance of failure in the creative process, and then facilitated an environment in which it was safe to fall flat on your face. Plenty of students can tell you about a professor who helped them succeed, but it's rare to speak so highly of a professor who helped you fail. ${ }^{1}$

Chet became my inspiration! The lightbulb went off! The "aha moment" struck! I was finally free of that irritating writer's block. What was the idea? Drum roll, please ...

I decided not to write about what I had learned about teaching entrepreneurship, assuming my audience for this volume is educators. I decided to write an open letter to my students, past and present, about what they had taught me about teaching entrepreneurship. If you "hear" in my writing how I talk to students, perhaps you can understand my teaching philosophy. This letter is dedicated to Chet and so many others who participated in my courses as I learned how to teach:

\section{Dear Student,}

I want to thank you for being a part of my life, because you have shaped who I am as an educator. I can never stop learning how to teach. If or when I do, I cease being an effective teacher. Every student who enters my classroom has taught me something about teaching, and I want to share these lessons that now form my teaching philosophy. 
You have helped me learn what works, how to keep you engaged, and how much I can push. I understand the importance of looking you in the eye, reading your body language, and listening - really listening. I anticipate and leverage those unexpected teaching moments that are uncomfortable yet unforgettable. These moments bind us.

I strive to practice what I preach. I demand that you think and act entrepreneurially, which requires you to develop creative solutions, take early action, accept and learn from small losses, and improvise when things do not go according to plan. I have to do the same. Teaching entrepreneurship requires continuous innovation, fearless experimentation and structured chaos.

I have learned that I must teach to excite, inspire, motivate and even shock you. I strive to create the unexpected in order to capture attention and spark enthusiasm for entrepreneurship - the necessary antecedents to learning. I have extremely high expectations with little tolerance for mediocrity and apathy, yet the culture of my classroom is open, playful and respectful. A class plan is necessary for organization and preparedness but not sufficient for student learning. Flexibility, humor, reactivity and improvisation are pillars of my philosophy.

Most importantly my approach to teaching is action-based. It has to be. In order to learn entrepreneurship one must do entrepreneurship. I have worked tirelessly to ensure you are able to practice aspects of entrepreneurship rather than be passive learners. Every day I strive to create a learning laboratory for experimentation and practice. You have taught me that action-based learning creates a sense of shared ownership in the learning process.

I encourage all students to use their voice - to debate, push back, and challenge me and their peers. I've developed the confidence to do the same. But I'll admit that the little things bother me. I have zero tolerance for unprofessional behavior. Arriving to class late, using smartphones and laptops inappropriately, and disrespecting me or other students have no place in my classroom. I will not hesitate to stop class, solve a particular issue and then restart class. You have taught me that ignoring bad behavior only perpetuates that behavior. And that behavior can become a cancer that spreads unless it is detected and stopped early. On the other hand patterns of negative behavior are 100 percent my fault. If half the class is consumed by their phones or computers then I am doing something wrong. If students are constantly arriving late or leaving during class to go [fill in the blank], I am doing something wrong. I am failing to engage; therefore, I must change my approach immediately.

The fact that I have no tolerance for unprofessional behavior does not mean I want a staid atmosphere. This would be the antithesis of 
entrepreneurship. I know that my courses need to be alive, exciting, relevant, challenging, creative, innovative and even playful and joyful. A community of learning and engagement must be omnipresent if we are going to transcend our preconceived notions of what entrepreneurship is and its importance in the world today. In other words, you have a huge responsibility as a nascent or practicing entrepreneur to create something of economic and social value to you and others.

I also have an enormous responsibility. Entrepreneurship is a complex phenomenon, chaotic, and lacking any notion of linearity. As an educator I have the responsibility to develop your discovery, thinking, reasoning, experimentation, and implementation skills so you may lead, manage, innovate and excel in highly uncertain entrepreneurial environments. These skills enhance the likelihood that you will identify and capture the right opportunity at the right time for the right reason. Entrepreneurs of all kinds impact the world, so entrepreneurship education is a necessary and formidable change agent. I really want you to do something great, take action and change your world! I will do everything I can to help facilitate your journey.

Keep entrepreneuring!

\section{Ray Smilor}

In my approach to teaching, I see myself as a guide. I lead students on a journey of self-discovery, a journey that reflects the entrepreneurial process itself - experiential throughout, surprising and unexpected at times, quite ambiguous now and then, intense on occasion, challenging and demanding most of the time, personally revealing, and potentially highly rewarding.

As a guide, I point direction but never dictate it. I warn of hazards but never prevent them. I don't predict but I do challenge. I debrief success and recognize the power of failure. I recognize talent but reward hard work. I encourage hope and bet on potential.

My philosophy is that each and every student is an entrepreneur capable of creative thinking and effective action. Interestingly, many students don't see themselves as either creative or entrepreneurial when they start my entrepreneurship courses. By the end, however, they are convinced that they are. How does this transformation happen?

\section{FIVE LESSONS}

Having taught entrepreneurship at all levels in many countries over the last 35 years, I have learned five key lessons that shape what I teach and how I teach it. 


\section{Create a Truly Different Learning Environment}

From the first moment of the first class, I want students to be bolted into believing that this class is really different from all others. Thus I learn the name of each student before they come into class and call them by name. That gets their attention! Then, before I introduce myself or discuss the syllabus, I conduct an experiential exercise that forces them to think unconventionally. For example, in my Opportunity Recognition class, I ask them "What is half of 13?" The first response is always 6.5. But I continue to ask over and over, "What is half of 13?" Eventually, we get to an incredibly wide range of answers that include 1,2,3,6,11, thir and teen, and many others, demonstrating that there is never just one right answer, that there is always more than one alternative, if one is daring enough to consider them.

In another class, I will introduce myself with a "bag resume." This presents a bisociative connection between a brown grocery store bag and the traditional paper resume. I pull six items out of the bag, each representing something that helped shape who I am as a person. It's unexpected, emotional and concrete. Then, in the next class, I have each student present their own bag resume as a way to demonstrate their own creativity and resourcefulness.

Even my syllabi are different. In my EMBA class on Innovation and Entrepreneurship, for example, I intersperse quotes, starting with Apple's 1997 "Think Different" commercial about crazies and genius, and end with Arthur Ashe's comment about the importance of one's reputation. I even include a cartoon about the entrepreneurial mindset.

If I can make each class really different from any other, then I can set high expectations, build enthusiasm and get the best out of each student.

\section{Instill an Entrepreneurial Attitude}

What does it mean to have an entrepreneurial attitude? For me, three elements are essential: a willingness to be wrong, a desire to make connections, and a belief that it is okay to fail. To instill these elements in students, I set up opportunities for them to test each element.

Sir Ken Robinson, the noted scholar on creativity, has pointed out that to be creative one must be willing to be wrong. In my classroom, this sometimes translates into the courage to look ridiculous. For example, I've required students to take dance lessons from a professor of classical dance. Once they do that they tend not to be afraid of anything! And they are much more willing to test out their own crazy ideas by ignoring the criticism of others!

Students too often believe that they must come up with an idea that 
no one ever thought about before to be successful. And yet real innovation often comes by making connections between things that people have thought a lot about before but never combined: a phenomenon that historian Arthur Koestler called bisociation - the ability to relate two seemingly unrelated things, to take two wildly different things and put them together. So, in my New Venture Development course, I utilize exercises that force unusual connections leading to business concepts that link apparently unrelated things - not only fun but practically useful.

I help students realize that successful entrepreneurs fail all the time. Through case studies, guest speakers, hands-on activities and their own efforts in class, they come to realize that mistakes demonstrate what is not working and needs fixing. The key is how we label failure. How we think about something affects how we feel about it and influences how we act towards it. In my classes, failure is not an end but another type of learning experience.

\section{Require Active Involvement and Engagement}

In my career, I have learned that, if one never speaks up, it is assumed that one has nothing to say. Thus I require that students speak up, and I grade them on their active involvement in each class on a 0 to 4 scale (a technique that I learned from case teacher Dave Rosenthal). Zero means a student has said nothing. Four means the student has made an important contribution to the discussion at hand. So, when we analyze a case or critique a business plan, my emphasis is not on the quantity of participation but the quality. I provide continual feedback to students on their participation. Because I know each student personally, they take this feedback constructively and come to class prepared to be engaged.

My focus is on both attitudes and behaviors. By requiring involvement and engagement, I not only look for thoughtful discussion but also expect students to participate in experiential exercises with an open mind, a positive approach, and a willingness to take some risk. Through interactive debriefs of class activities, and sometimes written "experience memos," I take time for each student to reflect on his or her own learning. Students thus must consider what they have experienced, identify their take-aways, and assess what specifically applies to their own behavior. Self-reflection thus becomes a kind of cement for the learning process.

\section{Promote "Yes, and" Behavior}

Entrepreneurs improvise. They have to make things up as they go along and often must operate in ambiguous circumstances. How do we help students 
get more comfortable in this type of environment? I believe lessons from improvisation are important here: to listen actively, to eliminate "no" and "but," and to stay in the moment. These are skills that students can learn and hone.

For me, "Yes, and" has been the key to my success, and I believe it is essential for the pursuit of opportunity. For example, when I have students interview an entrepreneur, I require that they explain what they have discovered that they did not set out to discover. This requires active listening and asking probing questions, important attributes in understanding and responding to the needs of others. In working in teams to generate ideas, they must avoid "no" and "but" and instead first communicate that they have understood the idea presented ("Yes") and then add something to expand or improve it ("and"). Lastly, to hone their "Yes, and" behavior, they must stay in the moment, that is, not jump ahead to push their own agenda but learn to focus on the person in front of them.

I help develop these skills with movie clips and experiential exercises. For example, I love the clip from Apollo 13 about the "Square Peg in a Round Hole," in which engineers have limited resources and limited time to solve an oxygen problem in the space craft. Thus I developed the Flying Device Game to simulate this situation. Students have to build a flying device from limited materials in a limited time that flies the farthest and the straightest - an exercise that emphasizes the "Yes, and" approach by dealing with problem-solving, team communication and innovation - and it's great fun.

\section{Address All Learning Styles}

We all learn differently. That is, we have different learning preferences. In my classes, I structure each session to address each style. As the Kolb Learning Style Inventory (which I have students complete) shows, there are four major learning styles of feeling (concrete experience), watching (reflective observation), thinking (abstract conceptualization) and doing (active experimentation). If I can structure a class to touch on all four, then I am more likely to keep their attention and bring out their best thinking and action. For students with a feeling orientation, I can use simulations, consulting projects and elevator pitches; for those with a watching orientation, I can utilize movies, demonstrations, guest speakers, and interviews with entrepreneurs; for those with a thinking orientation, I can include interactive lectures, case studies and special readings; for those with a doing orientation, I can bring in business plan development, company evaluations and hands-on experiences. 


\section{MY RESPONSIBILITY}

For me, entrepreneurship is not about starting a business, though that may be one outcome. It is about leading a more fulfilling life. It is about making the world a better place by finding one's purpose and then applying it to something personally meaningful. It is a mindset in which one pursues opportunity, creates values, communicates a compelling vision and maximizes limited resources in whatever career one chooses. So a person can be entrepreneurial in launching a startup venture, leading a growth enterprise, serving as an intrapreneur in a corporation, directing a government agency or even building an academic program.

I have taught at every level - elementary, secondary, undergraduate, graduate and executive education. And I've observed this: people learn what they want to learn. I want them to come out of my classes feeling as though the classes are the most useful, pertinent and engaging learning experience that they have ever had. For this to happen, I must address my responsibilities as a teacher: to prepare fully for each class, to give my best thinking and effort to every session, and to treat each student and his or her own hopes and aspirations with respect and dignity.

In each class, I must perform at my best. I use the term "perform" purposefully. Performance combines substance (real content) and form (genuine interest). Both are essential. If I am not deeply engaged and personally enthused, and visibly show these by my performance, then why should my students be? By performing at my best, maybe I can inspire and not just tally grades. For a teacher, there is joy in that.

To teach and to be taught by entrepreneurial students is a privilege. Every time I walk into my classroom, I remind myself of something: I don't have to do this; I get to do this. I get to make students aware of how creative and entrepreneurial they are. I get to share my experience and passion. I get to inspire. I get to teach entrepreneurship. What a deal!

\section{Bill Rossi}

Most effective professors report that they had a mentor, and that the mentor helped importantly to shape their style and teaching philosophy. When I began teaching entrepreneurship, I had no mentor. I had to find my own way. So I talked with students to identify who were their favorite teachers. I then watched the teachers at work by observing their classes. Each of these educators seemed to have a unique style, so identifying the best style to adopt seemed arbitrary. I concluded that I had to find my own comfort zone in developing a style that would reflect who I am rather than what I did, and a teaching objective that reflected what I wanted to 
accomplish. These two elements would have to then be guided by an overall teaching philosophy that reflected my personal values.

\section{TEACHING STYLE}

\section{Story Telling}

I began by trying to teach the concepts embodied in the entrepreneurial process, and met with limited initial success. My students were neither embracing these concepts nor seeing them as an overall process. Frustrated, I examined my approach and realized that the concepts were too ambiguous, and their relevance to students as individual concepts wasn't clear. Students could repeat them, but the concepts weren't being internalized or seen in the context of an overall entrepreneurship process.

While we teach that failure can be a good thing, for me it was not an option. Recalling that my favorite TED talks all featured stories, I crafted and incorporated stories from my personal entrepreneurial background that highlighted every concept in the entrepreneurial process. Success! Stories work; students love them. I'm a story teller now. Stories breathe life into entrepreneurial concepts, allowing them to be seen as an overall process.

\section{Teach Frameworks}

We are visual learners. Entrepreneurship is a discipline, replete with many concepts, but fundamentally it's a process, and every element of that process can be defined by a framework. I began by trying to teach concepts, but it's hard. Students failed to see the relationship between related concepts. The result was that they reverted to memorization, which precluded them from ever understanding entrepreneurship as a mindset. Frameworks define every major element of the entrepreneurship process, and teaching frameworks provide that visual reference. Frameworks enhance understanding of concepts, the relationship between them, and how ultimately the concepts all coalesce into a process that becomes the entrepreneurial mindset.

\section{Deliberate Practice}

Great pianists became great through intense practice. The same can be said of great football and basketball players. People learn most things through repeated practice. In particular, learning and internalizing the elements of 
the entrepreneurial process are best done through practice. As a strong proponent of experiential learning, every class day I teach some content, but then supplement this with repeated, deliberate practice of the concepts embodied in entrepreneurial competencies.

\section{Risk Taking}

We teach risk mitigation as an entrepreneurial competency, but I haven't encountered many good ways of experientially illustrating risk taking. So, a few years ago, I tried to incorporate risk in an entrepreneurship course. I proposed that the final exam be optional. If taken, there would be only two possible grades. Solid performance would result in a letter grade increase in course grade; poor performance would result in a letter grade reduction in course grade. Simple: a B pre-final could become either an A . . . or a C. The result was a colossal failure. Pre-final grades ranged from A- to C-. Every student in the class elected not to take a final exam. Apart from Dr. K's Spine Sweat course (which I don't personally have the risk posture to adopt), I still haven't found a good tool to teach risk, but feel strongly that one should be incorporated in teaching entrepreneurship.

\section{Enthusiasm}

I'm extremely enthusiastic teaching entrepreneurship; I even get excited. I think this draws students into class and gets them involved. My demeanor might be called a performance, although it is not. I'm simply tremendously enthusiastic about entrepreneurship as a discipline and its empowering and transformative nature, and I'm sincerely anxious to get my students to see it in the same light. Most students interpret my enthusiasm as passion for entrepreneurship, and my faculty evaluations reflect that.

\section{Compelling Presentations in the Classroom}

These are every bit as important as conveying a compelling vision for an entrepreneur. They're not dry nor given by a talking head, but are vibrant, full of enthusiasm, structurally logical, easily understood and delivered by someone who exudes passion for the topic. I practice core presentation skills:

1. Move around. (With a pedometer as my tool, my objective is 4000 steps per class. As they watch me move around, students are listening to me, and that's my objective.) 
2. Hand and body motions and vocal inflections make you animated, even entertaining. Without them you're a talking head and difficult to listen to for more than five minutes.

3. Direct eye contact. When you look at someone directly in the eye, you connect with that person. From then on, the person feels you are talking directly to him or her, no matter where you face.

\section{TEACHING OBJECTIVE}

My teaching objective is to train students to think, act and do in an entrepreneurial way in every aspect of their life. I want to inspire those that can be leaders, whether in business or other pursuits, to understand and embrace the entrepreneurial approach as a way of thinking. I want to instill in the others the sincere belief that contributors are just as important as leaders, but only if they too are entrepreneurial in their approach and become the very best that they can be in the way they've chosen to contribute.

\section{TEACHING PHILOSOPHY}

My teaching philosophy reflects my values, beliefs and passion for teaching entrepreneurship. Three tenets form that philosophy:

1. The best teachers are themselves students. Having practiced entrepreneurship for an entire career, I'm comfortable with my domain expertise. Scholarly research though regularly features new entrepreneurial concepts and sheds light on new applications of existing concepts. I'm a student of this research. My purpose is to challenge students, not only with the traditional concepts but with the newest cutting edge thinking about entrepreneurship. I work to be the perpetual student, to learn and then create an active learning environment where students will be challenged and inspired and will flourish.

2. Learning is facilitated by teachers who are respected by students. I've taught long enough now to have many students who have graduated and are well along in their careers. Some, and from many parts of the world, have started their own businesses and still stay in contact with me. Having thought a lot about this, I've come to believe these students stay in contact with me because they respected me, and now are seeking my respect. This to me illustrates the power of inspiration born of respect. 
I work hard to earn respect from every student, and the way I earn respect is to give respect. I respect every student as an individual and cater to his or her unique needs. I strive to find a shared perspective with each student. While this takes a lot of personal interaction, I find that students believe that I care for them as individuals. This creates respect for me, facilitating my ability to influence them through course content.

I respect their time. My office hours are any time, and include weekends.

Finally, I respect their efforts. Encouragement drives effort, so I easily complement clear thinking and solid effort. Challenge and encouragement are inseparable and are key elements in inspiring students' interest in entrepreneurship and their desire to learn more.

3. Substantial learning occurs outside of the classroom, where students review and discuss feedback and assessment of their deliverables. I believe that the learning process and permanent learning are advanced by providing substantive feedback for every deliverable, both constructive criticism and praise. This gives the student another opportunity to learn. Providing such extensive feedback is not without cost $-\mathrm{a}$ lot of time. But it's also not without value. Students regularly comment to me that they rarely receive such in-depth commentary on their work, and wished they did.

In summary, teaching entrepreneurship is not a job; it's a privilege. The style used to teach it I think has to be unique, and reflects one's comfort zone in terms of how one interacts with students. It is not something that can be observed in others and emulated. Teaching objectives can be similar among teachers. One's teaching philosophy I feel must also be unique, as it reflects one's values, beliefs and passion for teaching entrepreneurship.

\section{NOTE}

1. "Reflections from graduating students," Babson Magazine, Spring 2013, http://www. babson.edu/news-events/babson-magazine/spring-2013/babson-beyond/Pages/ reflections-from-graduating-students.aspx.

\section{REFERENCES}

Barnett, R. (2007), Will to Learn: Being a Student in an Age of Uncertainty, New York: Open University Press. 
Deleuze, G. (1990), The Logic of Sense, trans. M. Lester and C. Stivale, New York: Columbia University Press.

Felman, S. (1992), Education and crisis, or the vicissitudes of teaching, in S. Felman and D. Laub (eds.), Testimony: Crises of Witnessing in Literature, Psychoanalysis, and History, New York: Routledge, pp. 1-56.

Rilke, R.M. (1993), Letters to a Young Poet, trans. M.D. Herter, New York: Norton. 